
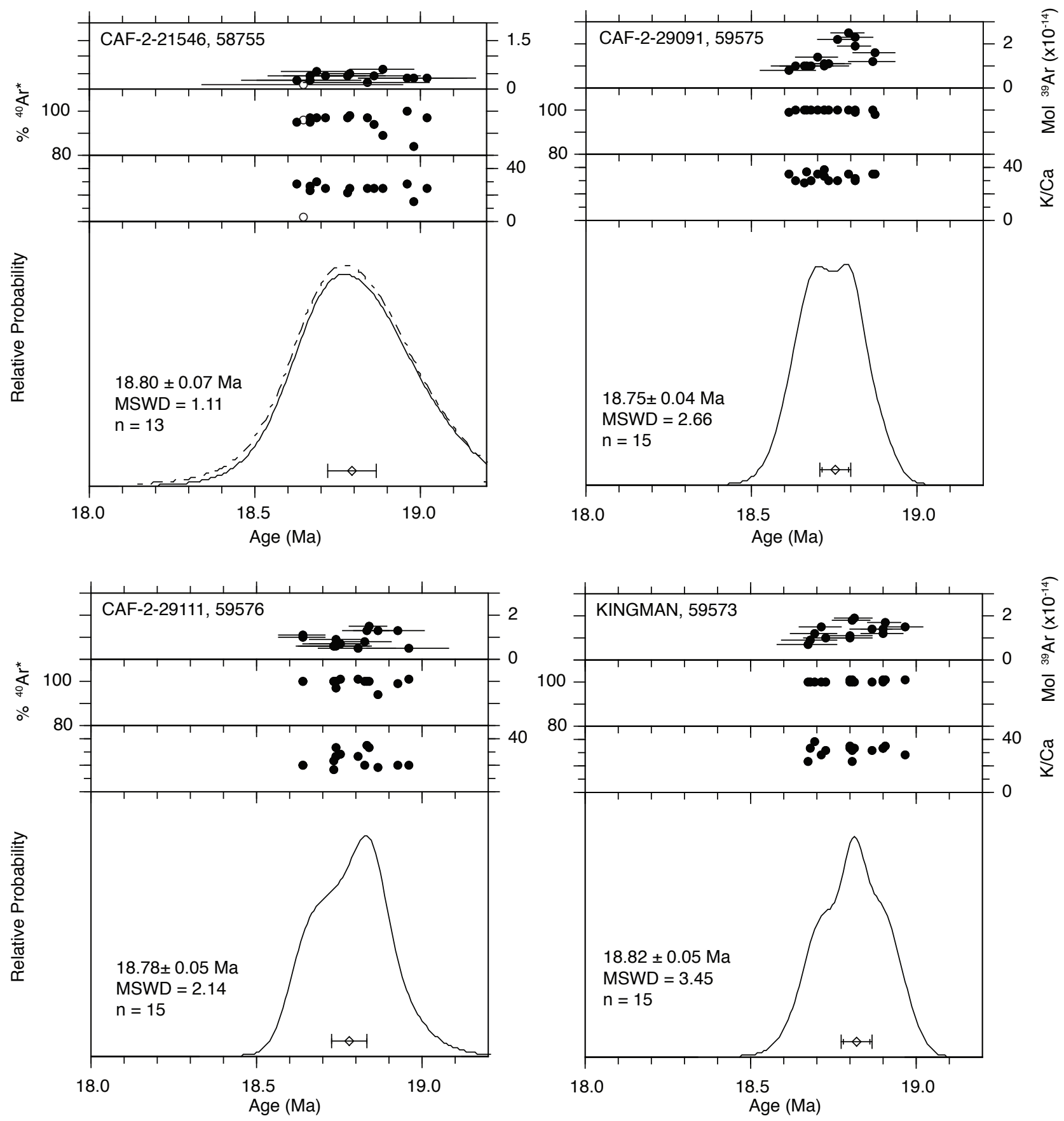

Figure DR1. ${ }^{40} \mathrm{Ar} /{ }^{39} \mathrm{Ar}$ dating single-crystal laser-fusion dating results from PST sanidine phenocrysts. For each sample, the stacked panels show ${ }^{39} \mathrm{Ar}$ signal size, percent of radiogenic ${ }^{40} \mathrm{Ar}, \mathrm{K} / \mathrm{Ca}$ ratio (calculated from measured ${ }^{39} \mathrm{Ar}_{\mathrm{K}} /{ }^{37} \mathrm{Ar} \mathrm{Ca}_{\mathrm{Ca}}$ ), and age probability distribution (Deino and Potts, 1990). Open symbols denote analyses not used in weighted mean age calculations. 

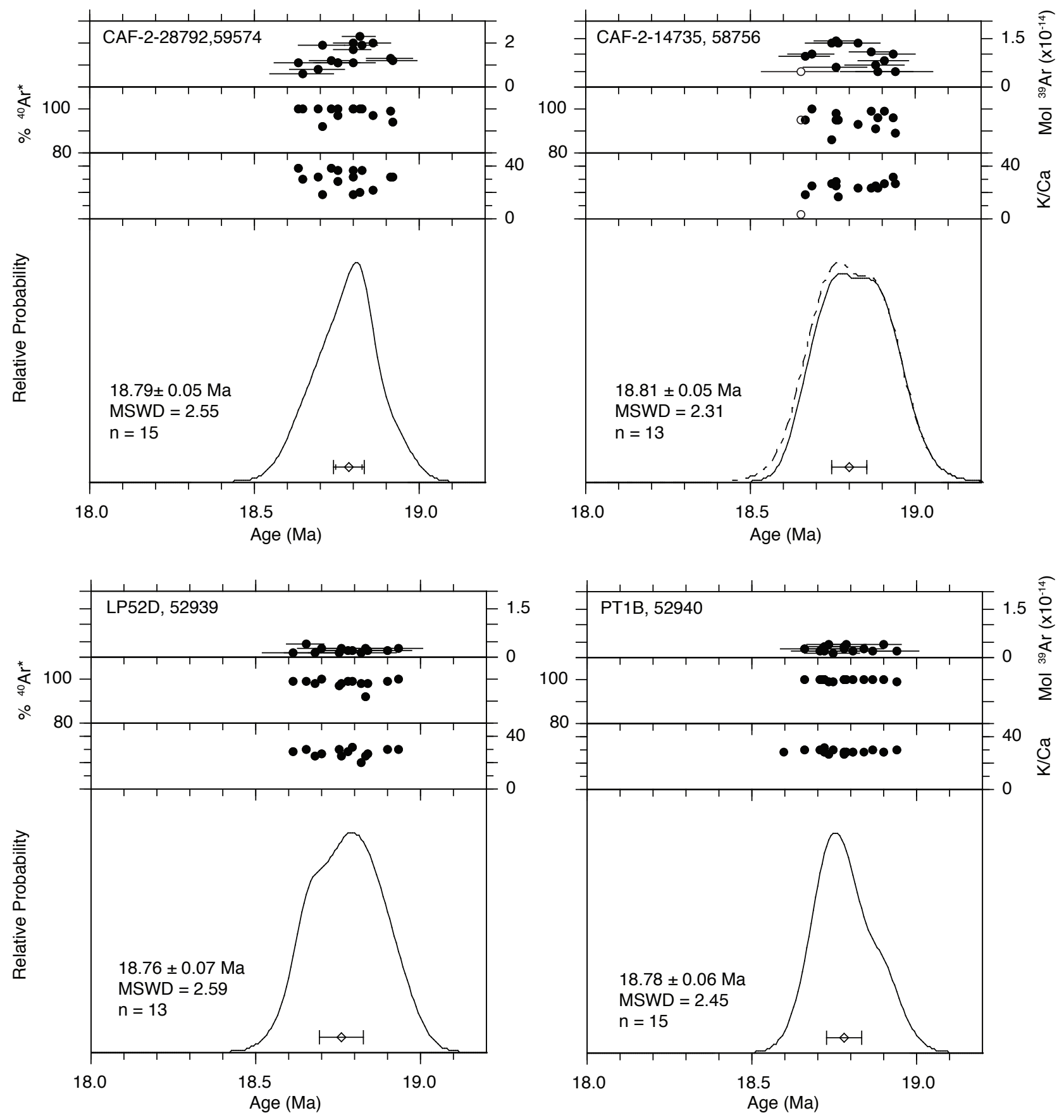

Figure DR1 (continued). ${ }^{40} \mathrm{Ar} /{ }^{39} \mathrm{Ar}$ dating single-crystal laser-fusion dating results from PST sanidine phenocrysts. For each sample, the stacked panels show ${ }^{39} \mathrm{Ar}$ signal size, percent of radiogenic ${ }^{40} \mathrm{Ar}, \mathrm{K} / \mathrm{Ca}$ ratio (calculated from measured ${ }^{39} \mathrm{Ar}_{\mathrm{K}}{ }^{37} \mathrm{Ar}_{\mathrm{Ca}}$ ), and age probability distribution (Deino and Potts, 1990). Open symbols denote analyses not used in weighted mean age calculations. 
Table DR1. ${ }^{40} \mathrm{Ar} /{ }^{39} \mathrm{Ar}$ analytical data.

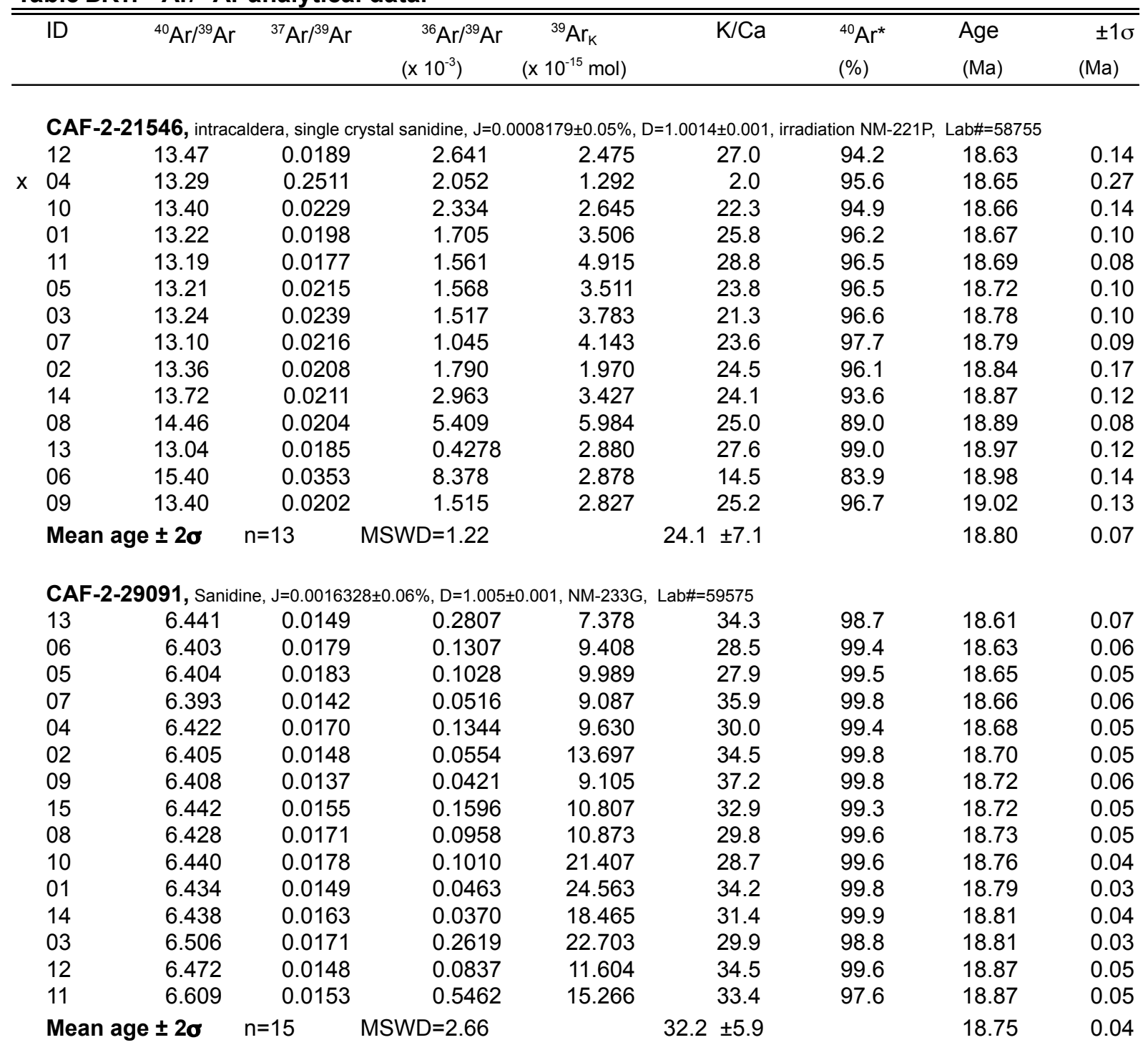




\begin{tabular}{|c|c|c|c|c|c|c|c|c|}
\hline \\
\hline 05 & 6.393 & 0.0276 & 0.1230 & 9.659 & 18.5 & 99.5 & 18.63 & 0.05 \\
\hline 12 & 6.385 & 0.0263 & 0.0932 & 10.183 & 19.4 & 99.6 & 18.64 & 0.05 \\
\hline 09 & 6.404 & 0.0230 & 0.0486 & 5.886 & 22.2 & 99.8 & 18.73 & 0.08 \\
\hline 11 & 6.426 & 0.0328 & 0.1248 & 5.217 & 15.6 & 99.5 & 18.73 & 0.09 \\
\hline 06 & 6.430 & 0.0153 & 0.1302 & 8.153 & 33.3 & 99.4 & 18.73 & 0.06 \\
\hline 13 & 6.408 & 0.0193 & 0.0509 & 5.038 & 26.5 & 99.8 & 18.74 & 0.0 \\
\hline 02 & 6.613 & 0.0194 & 0.7433 & 6.801 & 26.3 & 96.7 & 18.74 & 0.0 \\
\hline 10 & 6.397 & 0.0182 & 0.0020 & 6.956 & 28.1 & 100.0 & 18.75 & 0.0 \\
\hline 08 & 6.381 & 0.0202 & -0.1169 & 4.601 & 25.2 & 100.6 & 18.80 & 0.1 \\
\hline 01 & 6.427 & 0.0263 & 0.0162 & 7.909 & 19.4 & 100.0 & 18.83 & 0.0 \\
\hline 03 & 6.436 & 0.0152 & 0.0354 & 12.166 & 33.5 & 99.9 & 18.83 & 0.0 \\
\hline 15 & 6.438 & 0.0156 & 0.0360 & 14.925 & 32.7 & 99.9 & 18.84 & 0.8 \\
\hline 04 & 6.889 & 0.0278 & 1.534 & 12.879 & 18.3 & 93.4 & 18.87 & 0.0 \\
\hline 07 & 6.551 & 0.0265 & 0.3224 & 12.971 & 19.3 & 98.6 & 18.92 & 0.0 \\
\hline 14 & 6.466 & 0.0266 & -0.0082 & 4.402 & 19.2 & 100.1 & 18.96 & 0. \\
\hline & $2 \sigma$ & & $\mathrm{D}=2.14$ & & \pm 12. & & 18.78 & 0.0 \\
\hline
\end{tabular}

KINGMAN PST, Sanidine, $J=0.0016263 \pm 0.06 \%, D=1.005 \pm 0.001$, NM-233G, Lab\#=59573

\begin{tabular}{lllrrrrrr}
03 & 6.411 & 0.0223 & 0.0233 & 6.690 & 22.9 & 99.9 & 18.67 & 0.07 \\
16 & 6.417 & 0.0159 & 0.0343 & 8.103 & 32.1 & 99.9 & 18.68 & 0.06 \\
01 & 6.435 & 0.0139 & 0.0761 & 11.002 & 36.8 & 99.7 & 18.69 & 0.05 \\
13 & 6.446 & 0.0181 & 0.0907 & 14.910 & 28.1 & 99.6 & 18.71 & 0.04 \\
15 & 6.452 & 0.0170 & 0.0998 & 9.975 & 30.1 & 99.6 & 18.72 & 0.05 \\
06 & 6.446 & 0.0155 & -0.0093 & 10.670 & 32.8 & 100.1 & 18.80 & 0.05 \\
12 & 6.510 & 0.0148 & 0.2050 & 9.836 & 34.5 & 99.1 & 18.80 & 0.05 \\
14 & 6.479 & 0.0225 & 0.0968 & 17.303 & 22.6 & 99.6 & 18.80 & 0.04 \\
05 & 6.451 & 0.0165 & -0.0014 & 31.688 & 30.9 & 100.0 & 18.80 & 0.03 \\
11 & 6.469 & 0.0160 & 0.0519 & 18.912 & 31.8 & 99.8 & 18.81 & 0.04 \\
10 & 6.479 & 0.0161 & 0.0246 & 13.124 & 31.6 & 99.9 & 18.86 & 0.04 \\
04 & 6.491 & 0.0155 & 0.0268 & 11.251 & 32.8 & 99.9 & 18.90 & 0.05 \\
02 & 6.483 & 0.0161 & -0.0050 & 13.341 & 31.8 & 100.0 & 18.90 & 0.05 \\
08 & 6.481 & 0.0149 & -0.0124 & 16.858 & 34.3 & 100.1 & 18.90 & 0.04 \\
09 & 6.499 & 0.0187 & -0.0240 & 14.028 & 27.3 & 100.1 & 18.97 & 0.04 \\
\multicolumn{1}{l}{ Mean age } & $\mathbf{2 \sigma}$ & $\mathrm{n}=15$ & &
\end{tabular}

CAF-2-28792, Sanidine, $J=0.0016295 \pm 0.06 \%, D=1.005 \pm 0.001, N M-233 G$, Lab\#=59574

$\begin{array}{lllllllll}15 & 6.408 & 0.0139 & 0.0983 & 10.480 & 36.8 & 99.6 & 18.63 & 0.05 \\ 10 & 6.441 & 0.0172 & 0.2002 & 5.944 & 29.6 & 99.1 & 18.64 & 0.08 \\ 07 & 6.415 & 0.0161 & 0.0576 & 7.675 & 31.6 & 99.8 & 18.69 & 0.07 \\ 13 & 6.997 & 0.0284 & 2.015 & 18.274 & 18.0 & 91.5 & 18.70 & 0.05 \\ 03 & 6.451 & 0.0136 & 0.1339 & 12.000 & 37.6 & 99.4 & 18.73 & 0.05 \\ 09 & 6.460 & 0.0145 & 0.1394 & 10.697 & 35.3 & 99.4 & 18.75 & 0.05 \\ 02 & 6.663 & 0.0183 & 0.8262 & 10.981 & 27.8 & 96.4 & 18.75 & 0.06 \\ 01 & 6.482 & 0.0289 & 0.1636 & 10.993 & 17.7 & 99.3 & 18.79 & 0.05 \\ 14 & 6.474 & 0.0144 & 0.1303 & 19.655 & 35.3 & 99.4 & 18.80 & 0.04 \\ 04 & 6.441 & 0.0165 & 0.0165 & 16.842 & 30.9 & 99.9 & 18.80 & 0.04 \\ 08 & 6.484 & 0.0260 & 0.1432 & 22.119 & 19.6 & 99.4 & 18.82 & 0.03 \\ 06 & 6.449 & 0.0144 & 0.0153 & 18.337 & 35.4 & 99.9 & 18.82 & 0.04 \\ 05 & 6.710 & 0.0250 & 0.8599 & 19.984 & 20.4 & 96.2 & 18.86 & 0.04 \\ 11 & 6.588 & 0.0166 & 0.3825 & 12.795 & 30.7 & 98.3 & 18.91 & 0.05 \\ 12 & 6.914 & 0.0168 & 1.474 & 11.388 & 30.3 & 93.7 & 18.92 & 0.06 \\ \text { Mean age } & \mathbf{2 0} & \mathrm{n}=15 & & \end{array}$


CAF-2-14735, outflow, single crystal sanidine, $\mathrm{J}=0.0008177 \pm 0.05 \%, \mathrm{D}=1.0014 \pm 0.001$, irradiation $\mathrm{NM}-221 \mathrm{P}$, Lab\#=58756

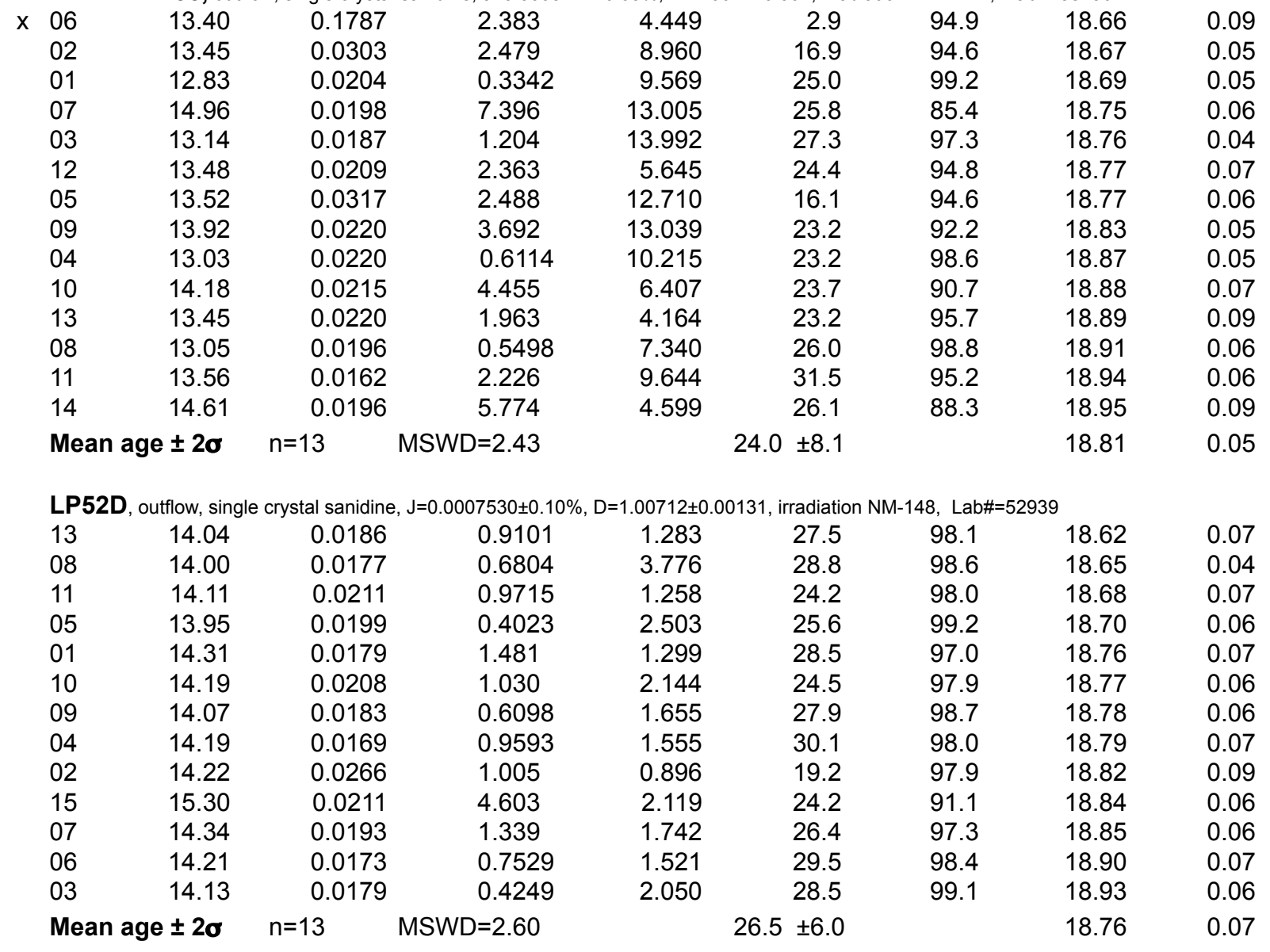

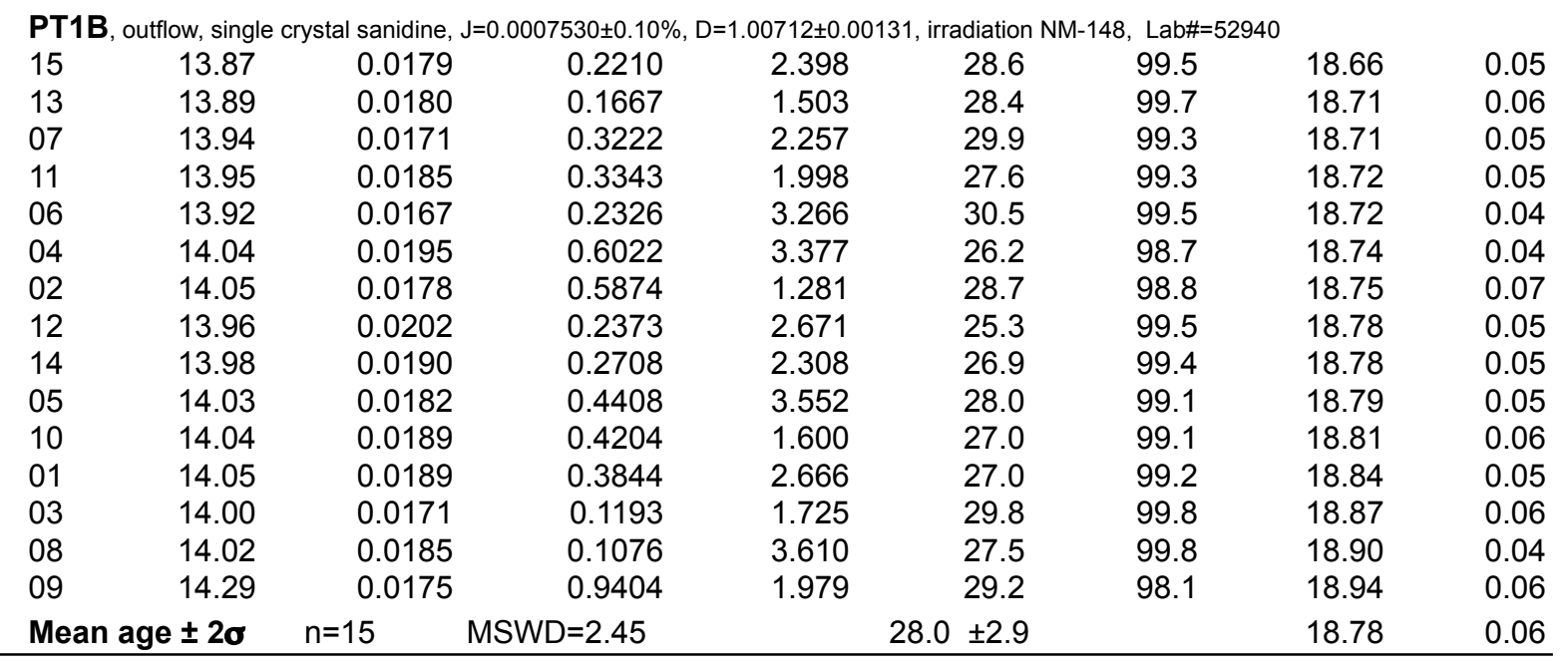


Notes:

x symbol preceding sample ID denotes analyses excluded from weighted mean age calculations. Isotopic ratios corrected for blank, radioactive decay, and mass discrimination, not corrected for interfering reactions. Errors quoted for individual analyses include analytical error only, without interfering reaction or $\mathrm{J}$ uncertainties.

\section{Age calculations:}

Ages calculated relative to FC-2 Fish Canyon Tuff sanidine interlaboratory standard (28.20 Ma, Kuiper et al., 2008).

Mean age is weighted mean age of Taylor (1982). Mean age error is weighted error

of the mean (Taylor, 1982), multiplied by the root of the MSWD where MSWD>1, and also

incorporates uncertainty in $\mathrm{J}$ factors and irradiation correction uncertainties.

MSWD (Mean Square Weighted Deviation) values are calculated for $\mathrm{n}-1$ degrees of freedom.

Decay constants and isotopic abundances after Steiger and Jäger (1977).

Individual analysis errors reported at $\pm 1 \sigma$, weighted mean age errors reported at $\pm 2 \sigma$.

\section{Sample preparation and irradiation:}

Sanidine separates prepared using crushing, dilute HF acid treatment, Franz magnetic separator, density liquids, and hand-picking techniques.

Samples were loaded into machined Al discs and irradiated in 3 separate batches (NM-148 and NM-221 each 7 hrs, D-3 position, Nuclear Science Center, College Station, TX, and NM-233, 7 hrs, Denver Triga Reactor). Neutron flux monitor Fish Canyon Tuff sanidine (FC-2).

\section{Instrumentation:}

Mass Analyzer Products 215-50 mass spectrometer on line with automated all-metal extraction system. Samples were fused using a CO2 laser (heating duration 30 seconds).

Reactive gases removed during laser analysis by reaction with 2 SAES GP-50 getters, 1 operated at $\sim 450^{\circ} \mathrm{C}$ and 1 at $20^{\circ} \mathrm{C}$. Gas also exposed to a W filament operated at $\sim 2000^{\circ} \mathrm{C}$.

\section{Analytical parameters:}

Electron multiplier sensitivity ranged from $3.3 \times 10^{-17}$ moles $/ \mathrm{pA}$ to $9.6 \times 10^{-17} \mathrm{moles} / \mathrm{pA}$.

Total system blank and background for the laser extraction sysytem averaged $299,4.8,1.1,25$, and $2.0 \times 10^{-18}$ moles at masses $40,39,38,37$ and 36 , respectively.

J-factors determined to a precision of $\pm 0.1 \%$ by $\mathrm{CO}_{2}$ laser-fusion of 6 single crystals from each of 10 radial positions around the irradiation tray.

$$
\begin{array}{ll}
\text { Correction factors NM-148: } & \text { Correction factors Irradiation NM-22 } \\
\left({ }^{39} \mathrm{Ar} /{ }^{37} \mathrm{Ar}\right)_{\mathrm{Ca}}=0.0007 \pm 2 \mathrm{e}-05 & \left.{ }^{39} /{ }^{37} \mathrm{Ar}\right)_{\mathrm{Ca}}=0.00068 \pm 5 \mathrm{e}-05 \\
\left({ }^{36} \mathrm{Ar} /{ }^{37} \mathrm{Ar}\right)_{\mathrm{Ca}}=0.00028 \pm 5 \mathrm{e}-06 & \left({ }^{36} \mathrm{Ar} /{ }^{37} \mathrm{Ar}\right)_{\mathrm{Ca}}=0.00028 \pm 2 \mathrm{e}-05 \\
\left({ }^{38} \mathrm{Ar} /{ }^{39} \mathrm{Ar}\right)_{\mathrm{K}}=0.01077 & \left({ }^{38} \mathrm{Ar} /{ }^{39} \mathrm{Ar}\right)_{\mathrm{K}}=0.0125 \\
\left({ }^{40} \mathrm{Ar} /{ }^{39} \mathrm{Ar}\right)_{\mathrm{K}}=0.0002 \pm 0.0003 & \left({ }^{40} \mathrm{Ar} /{ }^{39} \mathrm{Ar}\right)_{\mathrm{K}}=0 \pm 0.0004
\end{array}
$$

Correction factors NM-233:

$\left({ }^{39} \mathrm{Ar} /{ }^{37} \mathrm{Ar}\right)_{\mathrm{Ca}}=0.0007 \pm 2 \mathrm{e}-05$

$\left({ }^{36} \mathrm{Ar} /{ }^{37} \mathrm{Ar}\right)_{\mathrm{Ca}}=0.00028 \pm 5 \mathrm{e}-06$

$\left({ }^{38} \mathrm{Ar} /{ }^{39} \mathrm{Ar}\right)_{\mathrm{K}}=0.013$

$\left({ }^{40} \mathrm{Ar} /{ }^{39} \mathrm{Ar}\right)_{\mathrm{K}}=0.01 \pm 0.002$ 

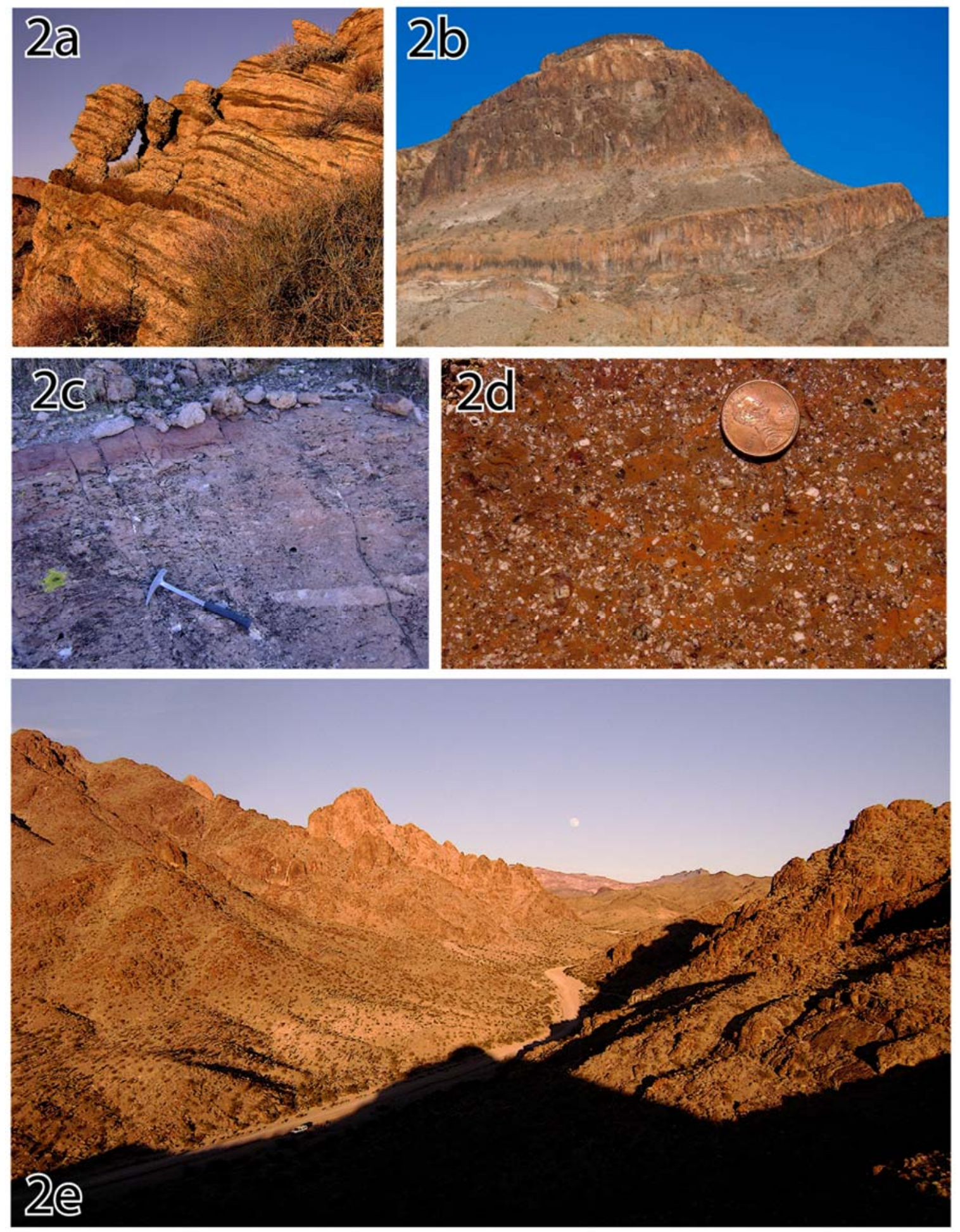

Figure DR2. a) Subaqueous, plagioclase-biotite phenocryst-rich ignimbrite in the lower division of the dacitic volcanics (Alcyone Formation of Thorson, 1971) southeast of Times Gulch, southern Black Mountains, Arizona, NAD83: 35.03556N, -114.44581. b) The $140 \mathrm{~m}$ thick section of outflow PST at Warm Springs, southern Black Mountains, Arizona. The dark cap is the phenocryst-rich trachyte vitrophyre mentioned in the text. The base is midway up the recessive 
slope where it overlies a welded, plagioclase-biotite phenocryst-rich ignimbrite (lower cliff), which in turn overlies a monotonous pile of plagioclase-biotite phenocryst-rich dacitic lava. View from NAD 83: 34.89167N, -114.31194. c) Photograph of peach and strawberry (felsic and mafic) pumice lapilli in proximal PST outflow $3 \mathrm{~km}$ west of Warm Springs, NAD83: 34.89167N, 114.37000. Outcrop is near date locality CAF-2-14735. d) Densely welded, feldspar phenocrystrich trachyte ignimbrite from the intracaldera dating locality, sample CAF-2-21456: NAD83: 35.04898, -114.47539. e) View to the east from NAD83: 35.03083, -114.46445 up Times Gulch along the southeastern margin of the Silver Creek caldera. Rocks to the south (right) are dacitic lava, ignimbrite, subaqueous ignimbrite, turbiditic sandstone, conglomerate, and breccia of the lower division of the dacitic volcanics (Alcyone Formation of Thorson, 1971). The Alcyone overlies Proterozoic granitoid at the base of the canyon (in shadow). Densely welded intracaldera PST lies to the north (left) and is intruded by Times granite porphyry, which forms the lighter, spire-shaped outcrops on the horizon. The crest of the Black Mountains northeast of Oatman near Sitgreaves pass, consisting of post-PST silicic volcanics, is barely visible on the skyline below the moon. 

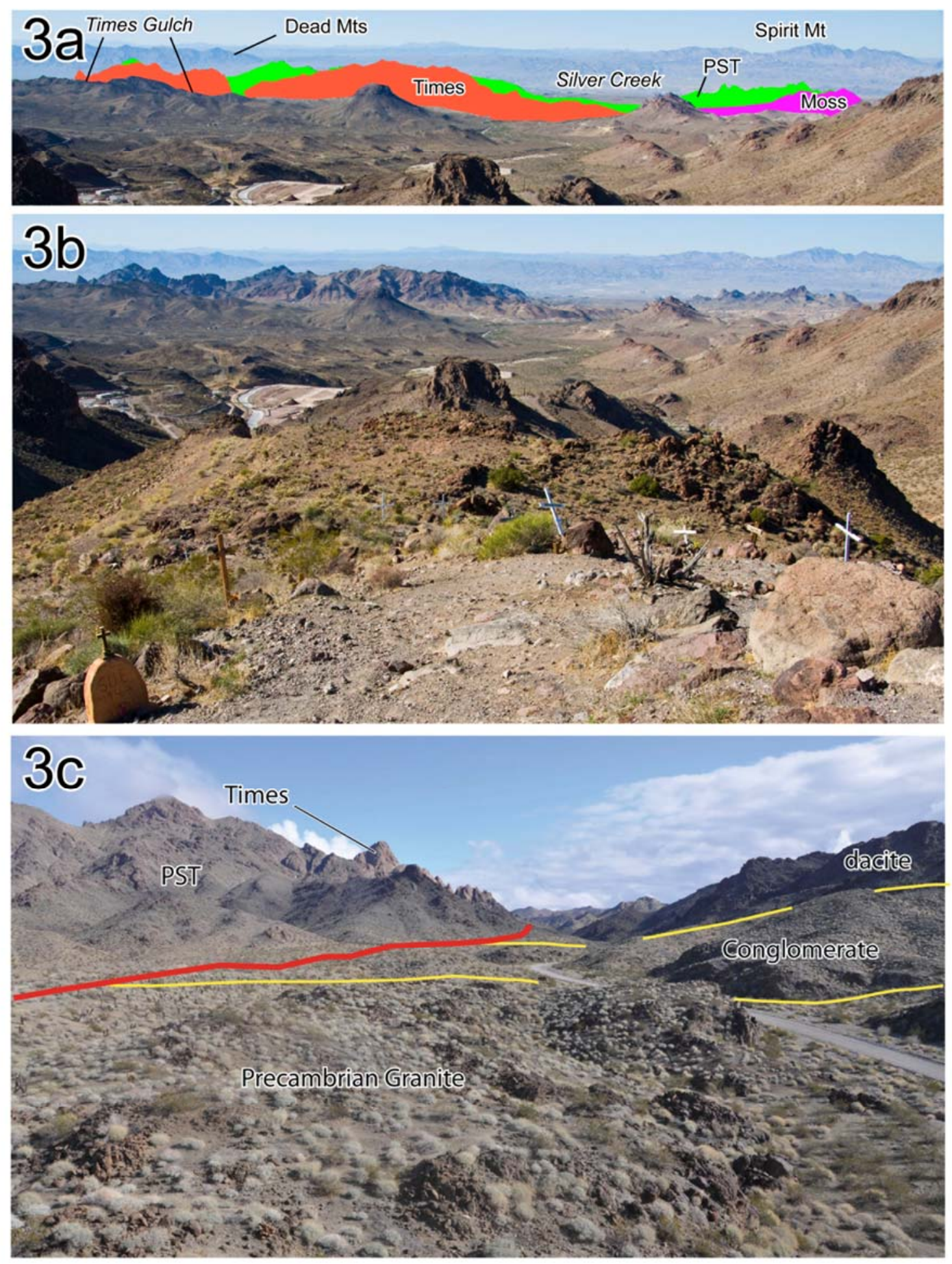

Figure DR3. a, b) View of the Silver Creek caldera to the west from overlook just west of Sitgreaves Pass, along US 66, Mohave County, Arizona (NAD83: 35.04675N, -114.36472); Goldroad Mine in the middle foreground. The Dead Mountains are in California, and Spirit Mountain is in the Newberry Mountains, Nevada. The Times and Moss porphyries intrude the eastern margin of the caldera. c) View to the east up Times Gulch showing pre-caldera 
stratigraphy (yellow) truncated to the north by the southern margin of the Silver Creek caldera (red). Vantage point: NAD83, 35.03144. -114.46964.
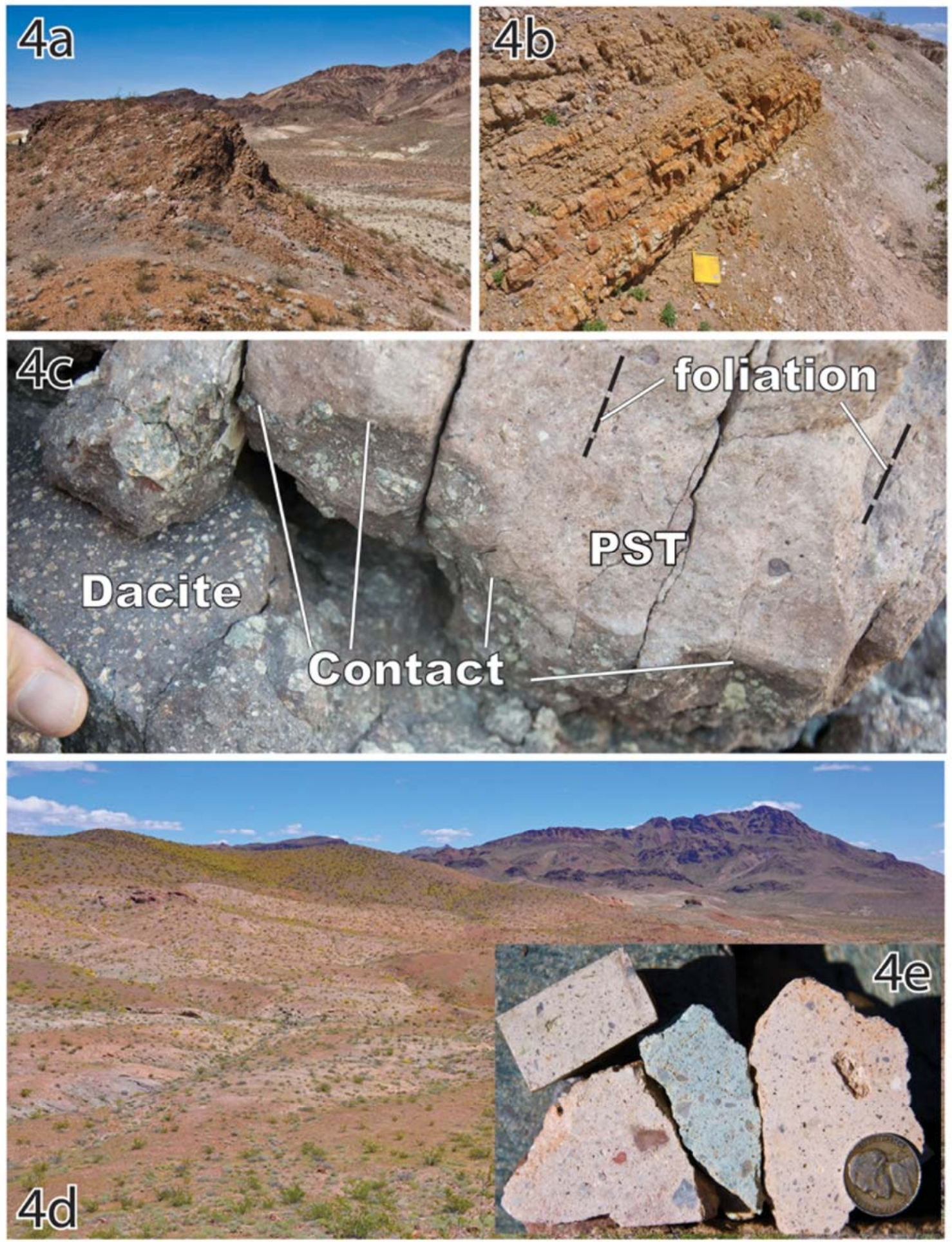

Figure DR. 4 a) Looking north at the middle of three knobs of welded ignimbrite identified as PST (McClelland, 1984) $2.25 \mathrm{~km}$ southwest $\left(230^{\circ}\right)$ of Eagle Peak, Sacramento Mountains, 
California, and the site of geochronology sample CAF-2-29091 (NAD83: 34.76635, -114.77535). The dark rock in the swale is the south end of a $75 \mathrm{~m}$ wide megablock of dacitic lava. The slope behind the knob is PST mesobreccia (light-color), which overlies lacustrine carbonate and phenocryst-rich subaqeous dacitic ignimbrite (light brown) in the middle distance. The north slope of Eagle Peak is on the horizon. b) A secquence of thin-bedded, subaqueous, plagioclasebiotite-phenocryst-rich ignimbrite underlies the PST near Eagle Peak. These rocks, pictured at NAD 83: 34.76960, -114.76985, are very similar to sequences of the Alcyone Formation (of Thorson, 1971) along Times Gulch in the Black Mountains (compare with Fig. 2a). c) View to the northwest of the northern edge of a $75 \mathrm{~m}$ megablock of dacite lava breccia in contact with welded ignimbrite (PST), NAD83 location: 34.76711, -114.77533. Eutaxitic foliation in the ignimbrite becomes more obvious away from the contact d) View to the northeast of lightly varicolored ignimbrite mesobreccia interpreted as intracaldera PST. Dark hills to the left consist of granite breccia in the hanging wall of a low-angle normal fault (McClelland, 1984). Eagle Peak, a 14.3 Ma rhyolite that intrudes and overlies the Sacramento Mts. detachment fault (Simpson et al., 1991) is on the right horizon. Photo vantage point is NAD83: 34.76697, 114.79195. e) Slabbed samples of ignimbrite mesobreccia for thin-section. Samples and their locations are from right to left: CAF-2-29114 (NAD83: 34.76729, -114.79789), CAF-2-29116 (NAD83: 34.76264, -114.79346), CAF-2-29097 (NAD83: 34.76308, -114.77946), and geochronology sample CAF-2-29111 (NAD83: 34.77045, -114.79514). 